\title{
STUDY OF THE PROPERTIES AND STRUCTURE OF SELECTED TOOL STEELS FOR COLD WORK DEPENDING ON THE PARAMETERS OF HEAT TREATMENT
}

\author{
ŠTUDIJA LASTNOSTI IN STRUKTURE IZBRANIH ORODNIH \\ JEKEL ZA HLADNO OBLIKOVANJE V ODVISNOSTI OD \\ TOPLOTNE OBDELAVE
}

\author{
Martin Kuřík, Jakub Lacza, Tomáš Vlach, Jana Sobotová \\ Czech Technical University, Faculty of Mechanical Engineering, Karlovo námesti 13, 12135 Prague 2, Czech Republic \\ martin.kurik@fs.cvut.cz
}

Prejem rokopisa - received: 2016-06-20; sprejem za objavo - accepted for publication: 2016-12-09

doi:10.17222/mit.2016.120

\begin{abstract}
Tool steels produced with powder metallurgy $(\mathrm{P} / \mathrm{M})$ are perspective materials, although they are more expensive in comparison with tool steels produced with the conventional method. The work focuses on the study of mechanical properties and structure depending on the heat-treatment conditions for the two tool steels. These are the 1.2379 steel for cold work produced with classical metallurgy and high-speed P/M steel Vanadis 23. Both materials were heat treated in the conventional manner to achieve a hardness of $61 \mathrm{HRC}$. They were also exposed to a cryogenic treatment at temperatures of $-90{ }^{\circ} \mathrm{C}$ and $-196{ }^{\circ} \mathrm{C}$ for $4 \mathrm{~h}$ between the hardening and the tempering. We evaluated the hardness and strength using the three-point-bending test and the wear resistance using the pin-on-disk method.

Keywords: powder metallurgy, high-speed steels, heat treatment, cryogenic treatment, wear rate
\end{abstract}

Orodna jekla, proizvedena s postopki metalurgije v prahu (angl. P/M) so perspektivni materiali, kljub temu da so dražji od tistih izdelanih s konvencionalno metodo. Delo je osredotočeno na študijo mehanskih lastnosti in strukturo, v odvisnosti od pogojev toplotne obdelave za ti dve vrsti orodnih jekel. To so jekla 1.2379 za delo v hladnem, proizvedena s klasičnimi metalurškimi postopki in hitrorezno P/M jeklo Vanadis 23. Oba materiala sta bila toplotno obdelana s konvencionalnimi postopki, glede na njuno sestavo, tako, da sta dosegli trdnost $61 \mathrm{HRC}$. Bili sta tudi izpostavljeni obdelavi s podhlajevanjem pri temperaturah od $-90{ }^{\circ} \mathrm{C}$ in $-196{ }^{\circ} \mathrm{C}$ za $4 \mathrm{~h}$ med strjevanjem in temperiranjem. Trdnost je bila ocenjena pri tritočkovnem mehanskem testu (zvijanje) in s testom obrabe po metodi pin-on-disk.

Ključne besede: metalurgija prahov, visokorezna jekla, toplotna obdelava, obdelava s podhlajevanjem, stopnja obrabe

\section{INTRODUCTION}

It is well known that for tool steels at a given hardness, the wear resistance may vary depending on the parameters of heat treatment and also on the mode of load for the tool during its use in manufacturing. In addition, we can assume that the resulting wear resistance will also affect the method of producing the material itself. As most of the tool steels are produced in the metallurgical process based on the solidification of the melt, this method can be classified as conventional (C/M). This metallurgy causes undesirable segregation that negatively affects the primarily toughness. In the tool steels produced with powder metallurgy $(\mathrm{P} / \mathrm{M})$, we achieve, in comparison with $\mathrm{C} / \mathrm{M}$, a finer and more homogeneous structure exhibiting better mechanical properties of the tools, such as greater toughness and wear resistance at higher cutting speeds. ${ }^{1}$ Although $\mathrm{P} / \mathrm{M}$ tool steels are several times more expensive compared with $\mathrm{C} / \mathrm{M}$ steels, they may be economically advantageous. The economic benefit of their use is particularly significant in the applications where the replacement of the tools is time consuming.
The present work deals with a comparison of the properties of selected tool steels for cold work with different primary-metallurgy steels, which were heat treated in a conventional manner (CHT), i.e., quenched and multiply tempered. Currently, the cryogenic treatment is increasingly used for tool steels. ${ }^{1-5}$ The aim is to obtain the optimum ratio between contradictory properties, like hardness and toughness, providing for a greater wear resistance of the treated instruments..$^{5}$ Authors attribute this benefit of cryogenic treatment to the precipitation of very fine carbides and a reduction of the proportion of the residual austenite in the structure. Cryogenic treatment usually takes place between quenching and tempering; its main parameters are the temperature and the holding time. Cryogenic treatment is generally divided, according to the minimum temperature, into: shallow cryogenic treatment (SCT), which is generally performed in a temperature range from $-80{ }^{\circ} \mathrm{C}$ to $-140{ }^{\circ} \mathrm{C}$ and deep cryogenic treatment (DCT), which is generally performed at a temperature of $-196{ }^{\circ} \mathrm{C} .5$ It can be said that, in the available literature, we can clearly find more publications dedicated to monitoring the effect of cryogenic treatment on the functional characteristics of 


\section{MATERIALI IN TEHNOLOGIJE/MATERIALS AND TECHNOLOGY (1967-2017) - 50 LET/50 YEARS}

\section{KUŘÍK et al.: STUDY OF THE PROPERTIES AND STRUCTURE OF SELECTED TOOL STEELS FOR COLD WORK ...}

the $\mathrm{C} / \mathrm{M}$ tool steel, compared with the publications that address the same issue for the $\mathrm{P} / \mathrm{M}$ steel. There are only a few papers about the benefits of the cryogenic treatment of high-speed steels (HSS). ${ }^{6,7}$ In the present work, we observe the influence of heat treatment on the properties of $\mathrm{C} / \mathrm{M}$ tool steel 1.2379 and $\mathrm{P} / \mathrm{M}$ HSS Vanadis 23. The work is part of the solution of a problem taken from practice, and the task is to find a more suitable material for a tool for cold forming and specify its heat treatment. A heat-treatment shop suggested to a customer to use cryogenically treated steel Vanadis 23 (1.3395) instead of steel 1.2379 (X153CrMoV12, AISI D2).

Steel 1.2379 is a C/M cold-work tool steel with high carbon and chromium contents. The steel is characterized with a high wear resistance, high compressive strength, good hardenability, high dimensional stability and good resistance to tempering. It is recommended for the tools that require a high wear resistance and sufficient toughness. The maximum hardness in the soft-annealed condition is $250 \mathrm{HBW}$. This steel is often used for cryogenic treatment as reported in references. ${ }^{2-4}$ It is noted that the steel showed an improvement in the wear resistance after cryogenic processing. For example, Das et al. investigated the effect of cryogenic treatment including low-temperature quenching and low-temperature tempering on the structure and properties of the 1.2379 steel. ${ }^{8,9}$ The authors conclude that both bulk hardness and apparent hardness of the matrix of the 1.2379 steel increase with the decreasing temperature of cryogenic treatments; however, this effect is more pronounced for the manifestation of the hardness of the matrix than of the bulk hardness. ${ }^{8}$ Furthermore, the authors note that the wear resistance of the 1.2379 steel gets considerably enhanced due to cryogenic treatment, compared to that of the $\mathrm{CHT}$ one, irrespective of the holding time at $-196{ }^{\circ} \mathrm{C}$.

The extent of the improvement in the wear resistance monitored with a pin-on-disk tester, however, is dependent on the test condition (using the normal load and sliding velocity). The authors attribute this fact to the wear-test condition, controlling the active mechanisms and the mode of wear. It was found that the hardness of the 1.2379 steel increases marginally due to cryogenic treatment, in contrast to a significant increase in the wear resistance. The most suitable parameters of DCT were determined for the 1.2379 tool steel, which are $-196{ }^{\circ} \mathrm{C} / 36 \mathrm{~h}$ for obtaining the best combination of the desired microstructure and wear properties of the steel. ${ }^{9}$
It is necessary to mention that at the used cooling and heating rate of $0.75 \mathrm{~K} / \mathrm{min}$ during the cryogenic treatment, the total time is 46 hours for DCT. Generally, when the time is longer, the processing is more expensive. This fact must also be included in the design of the parameters of DCT for real tools. ${ }^{10}$

Vanadis 23 (1.3395) is a chromium-molybdenum-tungsten-vanadium-alloyed high-speed $\mathrm{P} / \mathrm{M}$ steel which is characterized by an excellent combination of wear resistance and toughness, correct hardness for the application, very good dimensional stability during heat treatment and temper resistance. The maximum hardness in the soft-annealed condition is $260 \mathrm{HBW}$. It is especially suitable for blanking and forming thinner work materials where mixed (abrasive-adhesive) or abrasive types of the wear are encountered and where the risk for a plastic deformation of the working surface of a tool is high. We do not know of a research in the literature that would resolve the influence of heat-treatment conditions on the properties of this steel. However, C/M high-speed steel 1.3343 (AISI M2) is often used for cryogenic treatment according to references, ${ }^{6,11-12}$ as it has low carbon and vanadium contents in comparison with the other type of steel. Reference ${ }^{12}$ notes that no significant impact of DCT on the final hardness of steel 1.3343 was not proven, while its positive effect on the wear resistance was demonstrated. The wear resistance was observed to be greater by $44 \%$ after DCT, in comparison with that obtained after CHT using laboratory tests.

The tool life of twist drills made of steel increased after DCT, depending on the cutting conditions, in a range of $65-343 \%$. Conversely, reference ${ }^{11}$ notes that the hardness and also the wear resistance increase after DCT for steel 1.3343. A $6 \%$ increase in the hardness and a $35 \%$ increase in the wear resistance are established. It is stated in reference ${ }^{6}$ that moderate increases in the hardness and fracture toughness after DCT for steel 1.3343 result in a better wear resistance than in the case when only one of the parameters is extremely high. However, reference ${ }^{7}$ observes that the influence of DCT was not found for the hardness of P/M HSS Vanadis 30.

The aim of the present work was to investigate the effects of SCT and DCT taking place between quenching and tempering on the properties and structures of the two above-mentioned tool steels.

Table 1: Heat treatment of the experimental materials

\begin{tabular}{|c|c|c|c|c|}
\hline Material & Quenching & Cryogenic treatment & Tempering & Designation of the regime \\
\hline 1.2379 & $1050{ }^{\circ} \mathrm{C} / 30 \mathrm{~min}$ & - & $2 \times 500{ }^{\circ} \mathrm{C} / 2 \mathrm{~h}$ & $\mathrm{CHT}$ \\
\hline 1.2379 & $1050{ }^{\circ} \mathrm{C} / 30 \mathrm{~min}$ & $-90{ }^{\circ} \mathrm{C} / 4 \mathrm{~h}$ & $2 \times 500{ }^{\circ} \mathrm{C} / 2 \mathrm{~h}$ & SCT \\
\hline 1.2379 & $1050{ }^{\circ} \mathrm{C} / 30 \mathrm{~min}$ & $-196{ }^{\circ} \mathrm{C} / 4 \mathrm{~h}$ & $2 \times 500{ }^{\circ} \mathrm{C} / 2 \mathrm{~h}$ & DCT \\
\hline Vanadis 23 & $1050{ }^{\circ} \mathrm{C} / 5 \mathrm{~min}$ & - & $3 \times 560{ }^{\circ} \mathrm{C} / 1 \mathrm{~h}$ & $\mathrm{CHT}$ \\
\hline Vanadis 23 & $1050{ }^{\circ} \mathrm{C} / 5 \mathrm{~min}$ & $-90{ }^{\circ} \mathrm{C} / 4 \mathrm{~h}$ & $3 \times 560{ }^{\circ} \mathrm{C} / 1 \mathrm{~h}$ & SCT \\
\hline Vanadis 23 & $1050{ }^{\circ} \mathrm{C} / 5 \mathrm{~min}$ & $-196{ }^{\circ} \mathrm{C} / 4 \mathrm{~h}$ & $3 \times 560^{\circ} \mathrm{C} / 1 \mathrm{~h}$ & DCT \\
\hline
\end{tabular}




\section{EXPERIMENTAL PART}

The experimental material included commercial $\mathrm{C} / \mathrm{M}$ cold-work steel 1.2379 (X153CrMoV12, AISI D2), nominally containing (in mass fractions, $w / \%) 1,53 \% \mathrm{C}$, $0,35 \% \mathrm{Si}, 0,45 \% \mathrm{Mn}, 12,00 \% \mathrm{Cr}, 0,85 \% \mathrm{Mo}$, $0,85 \% \mathrm{~V}$ and P/M HSS Vanadis 23 (1.3395) nominally containing (in mass fractions, $w / \%$ ) $1,29 \% \mathrm{C}, 058 \% \mathrm{Si}$, $0,29 \% \mathrm{Mn}, 0,024 \% \mathrm{P}, 0,014 \% \mathrm{~S}, 4,02 \% \mathrm{Cr}$, $4,91 \% \mathrm{Mo}, 6,13 \% \mathrm{~W}, 2,97 \% \mathrm{~V}$. The choice of the materials was explained in the introduction. Samples for the three-point-bending test $(10 \times 10 \times 100 \mathrm{~mm}$ with surface roughness of $0.2-0.3 \mu \mathrm{m}$ ) were made from the two materials. CHT consisted of the following steps for both materials: austenitizing, quenching and double or triple tempering. Cryogenic processing also included hardening and tempering of each material. The heat-treatment regime is shown in Table 1. Five samples of each series were processed.

The distance between supports was $80 \mathrm{~mm}$ during the three-point-bending test; the loading rate was $1 \mathrm{~mm} / \mathrm{min}$ up to the moment of fracture. The average values and standard deviation were calculated from the measured values. Broken specimens were used for measuring the HRC hardness. The hardness was measured five times on each sample and the average values and standard deviation were calculated. One specimen whose strength was close to the average value was chosen from each series. These samples served for a metallographic analysis and the measurement of the wear resistance. A basic metallographic analysis was performed using light microscopy of cross-section samples. Metallographic samples were prepared in the standard way and etched with $2 \%$ Nital.

SEM micrograhps were taken with a JOEL JSM7600F device. The wear resistance was determined with the pin-on-disk tester in line with the standard. ${ }^{13}$ As the disk was used for testing the material, its surface was polished to a surface roughness better than $0.04 \mu \mathrm{m}$. The test was carried out under dry sliding conditions, performed at a room temperature of $22{ }^{\circ} \mathrm{C}$ and relatively humidity of $60 \%$. All the specimens were ultrasonically

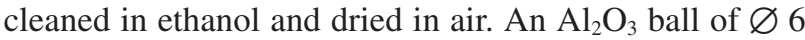
$\mathrm{mm}$ was used as the counterpart. The sliding speed was $6.4 \mathrm{~cm} / \mathrm{s}$, the total sliding distance was $100 \mathrm{~m}$ and the scratch radius was $4 \mathrm{~mm}$. The width of scratches was

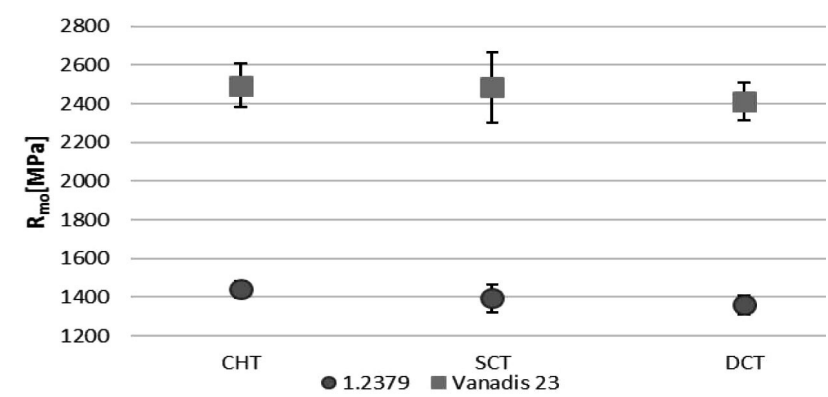

Figure 1: Influence of heat treatment on the bending strength of 1.2379 and Vanadis 23 steels evaluated with light microscopy using a Nis Elements image analyser, always at six locations. The average value was calculated and the wear rate was determined. Control measurements were performed in the transverse area of the scratches using a profilometer, recording a good range of the results.

\section{RESULTS AND DISCUSSION}

The bending strength for both materials is shown in Figure 1. As expected, the strength of steel Vanadis 23 is about $1000 \mathrm{MPa}$ higher than that of steel 1.2379. As stated by the author in reference ${ }^{14}$, the flexural strength is dependent, among other things, on the size and distribution of carbides. For steel Vanadis 23, a more uniform distribution of small carbides is expected than in the case of steel 1.2379. Fracture was always brittle to form two large parts and small fragments of the fracture surface. The measurement was conducted only for the purpose of comparison.

It can be concluded that the bending strength was almost identical depending on the heat treatment of both steels. This result is in good agreement with the results of previous works. ${ }^{7,15}$ As expected, the hardness of steel Vanadis 23 is 1-2 HRC higher than the hardness of steel 1.2379 (Figure 2).

It seems that the hardness values slightly decreased for the two reference materials after cryogenic processing, which is in good agreement with the results of monitoring the impact of cryogenic treatment on the properties of P/M tool steel Vanadis $6 .^{15,16}$ On the contrary, D. Das $^{8}$ concluded that both the bulk hardness and the apparent hardness of the matrix increase with the decreasing temperature of cryogenic treatments of the $\mathrm{C} / \mathrm{M}$ 1.2379 steel, and that the degree of influence of cryogenic treatment on the hardness is dependent on the parameters of the heat treatment (the temperature and time of austenizing and tempering) as well as the rate of cooling, depth of cryogenic treatment and holding time. However, it should be noted that in his case, low-temperature tempering was used.

The microstructures of steels 1.2379 and Vanadis 23 after CHT and DCT are shown in Figure 3. The microstructure of both steels consists of the matrix and carbides. The distribution and size of carbides differ, de-

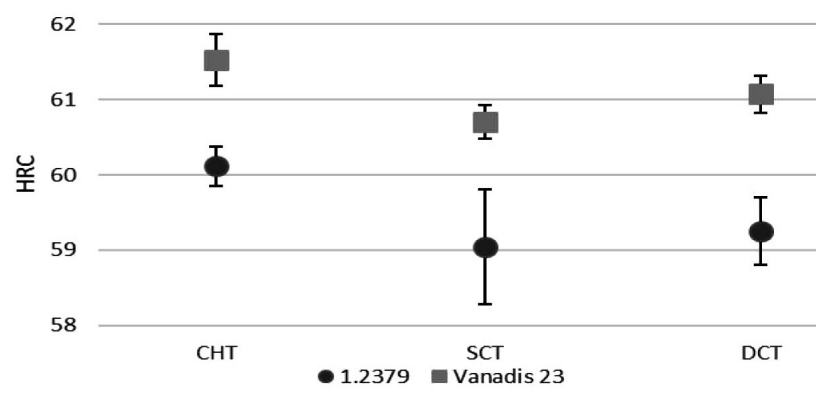

Figure 2: Influence of heat treatment on the hardness of 1.2379 and Vanadis 23 steels 
M. KUŘÍK et al.: STUDY OF THE PROPERTIES AND STRUCTURE OF SELECTED TOOL STEELS FOR COLD WORK ...
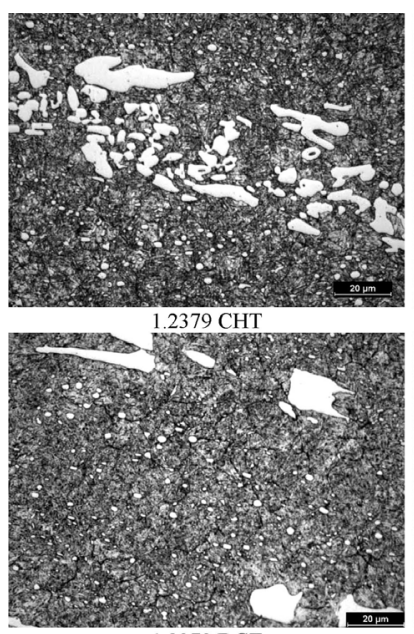

$1.2379 \mathrm{DCT}$
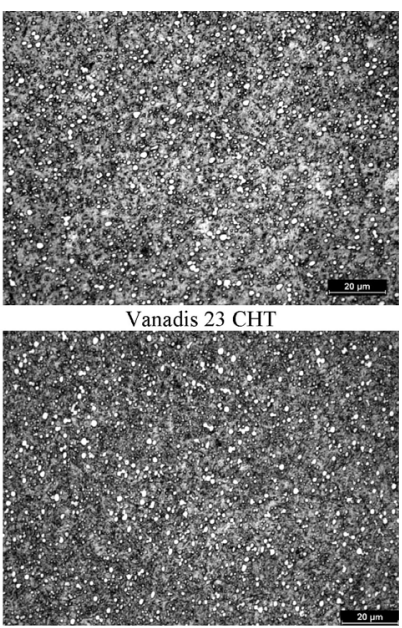

Vanadis 23 DCT

Figure 3: Microstructures of 1.2379 and Vanadis 23 steels after CHT and DCT

pending on the method of steelmaking $(\mathrm{C} / \mathrm{M}$ or $\mathrm{P} / \mathrm{M})$. The banding carbides observed in steel 1.2379 confirm the measurement of the bending strength. In both cases, the matrix mainly contains tempered martensite. Minor phases include retained austenite. It can be expected that the amount of retained austenite and precipitated fine carbides is smaller after DCT than after CHT. ${ }^{2-4}$

The SEM analysis did not show any significant differences in the structure between CHT, SCT and DCT. No significant areas of residual austenite were observed, as illustrated in Figure 4. A TEM analysis was necessary for an accurate determination of the amount of residual austenite. In both cases, we observed small carbides with sizes smaller than 1 micron, but in the case of Vanadis 23, their amount was significantly larger. Moreover, its structure included carbides with sizes of 100-200 nm.

The wear rate was determined for both materials and monitored states (Figure 5). As expected, it is seen that
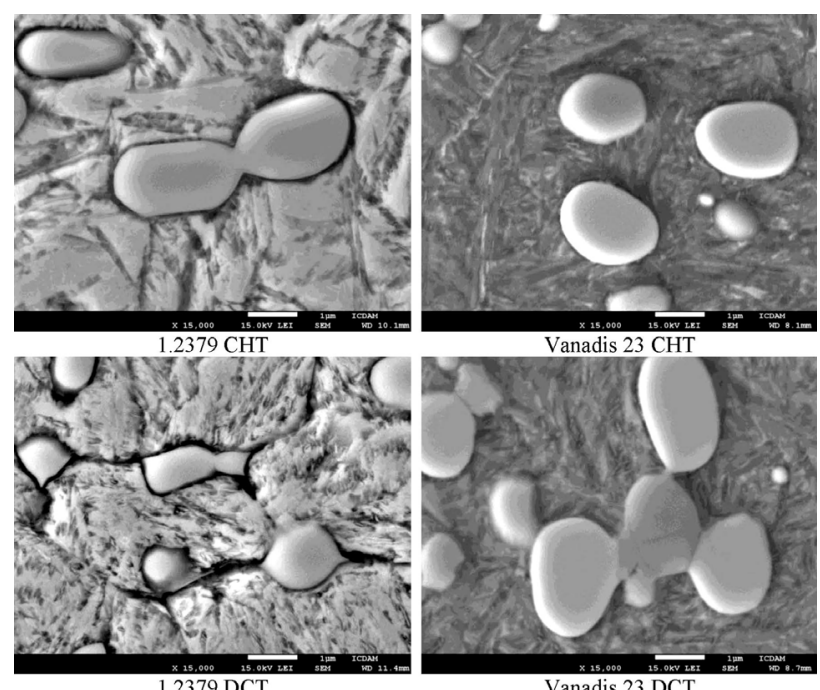

Figure 4: SEM micrographs of 1.2379 and Vanadis 23 steels after CHT and DCT

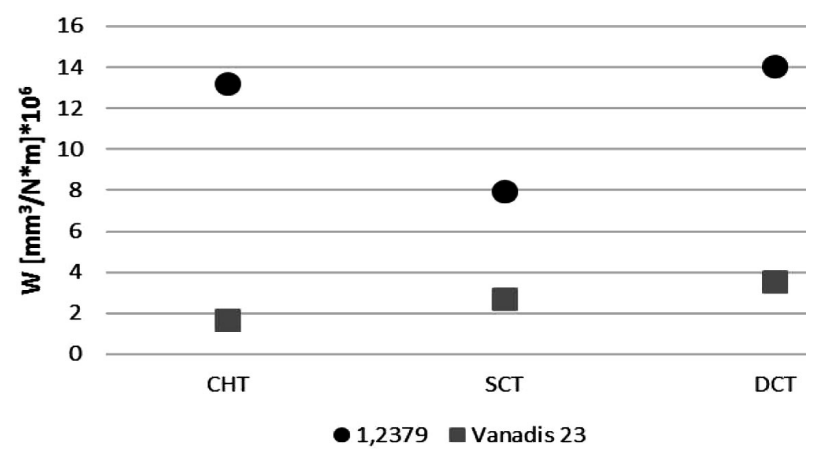

Figure 5: Influence of heat treatment on the wear rate of 1.2379 and Vanadis 23 steels

the wear-rate values are much lower for Vanadis 23 than for steel 1.2379. The wear rate of steel Vanadis 23 depends on the heat treatment, but it varies minimally. It was necessary to verify the value of the wear rate of steel 1.2379 after SCT. The existing results and the results from reference ${ }^{9}$ do not indicate that the wear rate should be lower after SCT than after DCT of the 1.2379 steel. Based on these laboratory results, it is possible to believe that Vanadis 23 is a suitable material for the replacement of steel 1.2379 in the case of cold forming. Although the current results of the pin-on-disk test do not conform to our assumption, it can be assumed that the tools made of steel Vanadis 23 using DCT have better wear resistance than the tools after CHT. The results may be distorted because the formed wear-track width was between 200-300 microns, which is about $5 \%$ of the diameter of the inserted $\mathrm{Al}_{2} \mathrm{O}_{3}$ ball. Based on this finding, it would be preferable to use a larger normal load for the pin-on-disc test for the wear-track width to be in a range of $20-80 \%$ of the ball diameter. Yan ${ }^{10}$ states that although the hardness and wear tests provided information on the properties of the cryogenically treated HSS, they may not properly represent the loads of real tools in the operating conditions. For this reason, the heat treatment of P/M HSS Vanadis 23 will be recommended after a durability test of real tools.

\section{CONCLUSIONS}

The obtained results and our pertinent discussion allow us to infer the following:

- The bending-strength values were almost identical after the conventional and cryogenic treatment of C/M tool steel 1.2379 and P/M HSS Vanadis 23. The strength of steel Vanadis 23 was about $1000 \mathrm{MPa}$ higher than that of steel 1.2379 in all the modes of heat treatment.

- The hardness values for the two reference materials slightly decreased after the cryogenic processing. The hardness of steel Vanadis 23 was 1-2 HRC higher than the hardness of steel 1.2379 . 


\section{MATERIALI IN TEHNOLOGIJE/MATERIALS AND TECHNOLOGY (1967-2017) - 50 LET/50 YEARS}

\section{KUŘíK et al.: STUDY OF THE PROPERTIES AND STRUCTURE OF SELECTED TOOL STEELS FOR COLD WORK ...}

- Light metallography is not appropriate for investigating structural changes after the cryogenic treatment of the 1.2379 and Vanadis 23 steel.

- The wear-rate values are much lower for Vanadis 23 than for steel 1.2379 .

- Based on these laboratory results, Vanadis 23 is a suitable material for the replacement of steel 1.2379 in the case of cold forming.

- The inclusion of a cryogenic treatment in the conventional heat treatment of Vanadis 23 will be decided on after a durability test of real tools.

\section{Acknowledgements}

This work was supported by the Ministry of Education, Youth and Sport of the Czech Republic, programe NPU1, project No. LO1207 and by the Grant Agency of the Czech Technical University in Prague, grant No. SGS15/149/OHK2/2T/12.

\section{REFERENCES}

${ }^{1}$ S. Akincioğlu, H. Gökkaya, İ. Uygur, A review of cryogenic treatment on cutting tools, The Inter. J. of Advanced Manufacturing Technology, 78 (2015), 1609-1627, doi:10.1007/s00170-014-6755-x

${ }^{2}$ S. S. Gill, J. Singh, R. Singh, H. Singh, Metallurgical principles of cryogenically treated tool steels, A review on the current state of science, The International Journal of Advanced Manufacturing Technology, 54 (2011), 59-82, doi:10.1007/s00170-010-2935-5

${ }^{3}$ N. S. Kalsi, R. Sehgal, V. S. Sharma, Cryogenic Treatment of Tool Materials: A Review, Materials and Manufacturing Processes, 25 (2010), 1077-1100, doi:10.1080/10426911003720862

${ }^{4} \mathrm{P}$. F. Stratton, Optimising nano-carbide precipitation in tool steels, Materials Science and Engineering A, 449-451 (2007), 809-812, doi:10.1016/j.msea.2006.01.162
${ }^{5}$ P. Baldissera, C. Delprete, Deep Cryogenic Treatment: A Bibliographic Review, The Open Mechanical Engineering Journal, Benthham Science Publishers Ltd., 2 (2008), 1-11

${ }^{6}$ V. Leskovšek, M. Kalin, J. Vižintin, Influence of deep-cryogenic treatment on wear resistance of vacuum heat-treated HSS, Vacuum, 80 (2006) 6, 507-518, doi:10.1016/j.vacuum.2005.08.023

${ }^{7}$ J. Sobotová, M. Kuřík, J. Cejp, Influence of Heat Treatment Conditions on Properties of High-Speed P/M Steel Vanadis 30, Key Engineering Materials, 647 (2015), 17-22, doi: 10.4028/www.scientific.net/KEM.647.17

${ }^{8}$ D. Das, A. K. Dutta, K. K. Ray, Sub-zero treatments of AISI D2 steel: Part I, Microstructure and hardness, Materials Science and Engineering A, 527 (2010), 2182-2193, doi:10.1016/j.msea.2009. 10.070

${ }^{9}$ D. Das, A. K. Dutta, K. K. Ray, Influence of varied cryotreatment on the wear behavior of AISI D2 steel, Wear, 266 (2009), 297-309, doi: 10.1016/j.wear.2008.07.001

${ }^{10}$ X. G. Yan, D. Y. Li, Effects of the sub-zero treatment condition on microstructure, mechanical behavior and wear resistance of W9Mo3Cr4V high speed steel, Wear, 302 (2013), 854-862, doi:10.1016/j.wear.2012.12.037

${ }^{11}$ A. Molinari, M. Pellizzari, S. Gialanella, Effect of deep cryogenics treatment on the mechanical properties of tool steels, Journal of Material Processing Technology, Elsevier Science B.V., 118 (2001), 350-355, doi:10.1016/S0924-0136(01)00973-6

${ }^{12}$ F. J. Da Silva, S. D. Franco, Á. R. Machado, E. O. Ezugwu, Performance of cryogenically treated HSS tools, Wear, 261 (2006), 674-685, doi:10.1016/j.wear.2006.01.017

${ }^{13}$ Standard Test Method for Wear Testing with a Pin-on-Disk Apparatus: G99-05, Reapproved, ASTM International, 2010, USA

${ }^{14}$ P. Jurči, Tool steel of the ledeburutuc type, Czech Technical University Prague, 2009, 221

${ }^{15}$ J. Sobotová, P. Jurči, I. Dlouhý, The effect of sub-zero treatment on microstructure, fracture toughness and wear resistance of Vanadis 6 tool steel, Materials Science and Engineering A, 652 (2016), 192-204, doi:10.1016/j.msea.2015.11.078

${ }^{16}$ J. Sobotová, P. Jurči, J. Cejp, Structure and Properties of Sub-Zero Processed Vanadis 6, Metal 2011 - 20th International Conference on Metallurgy and Materials, Ostrava, 2011, 672-677 